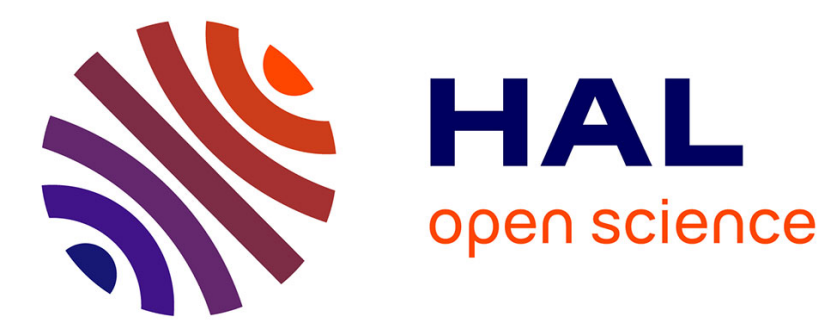

\title{
Synthetic fuels from biomass using concentrated solar energy - A review
}

\author{
Ange Nzihou, Gilles Flamant, Brian Stanmore
}

\section{To cite this version:}

Ange Nzihou, Gilles Flamant, Brian Stanmore. Synthetic fuels from biomass using concentrated solar energy - A review. Energy, 2012, 42 (1), pp.121-131. 10.1016/j.energy.2012.03.077 . hal-01632404

\section{HAL Id: hal-01632404 \\ https://hal.science/hal-01632404}

Submitted on 23 Jan 2019

HAL is a multi-disciplinary open access archive for the deposit and dissemination of scientific research documents, whether they are published or not. The documents may come from teaching and research institutions in France or abroad, or from public or private research centers.
L'archive ouverte pluridisciplinaire HAL, est destinée au dépôt et à la diffusion de documents scientifiques de niveau recherche, publiés ou non, émanant des établissements d'enseignement et de recherche français ou étrangers, des laboratoires publics ou privés. 


\title{
Synthetic fuels from biomass using concentrated solar energy - A review
}

\author{
Ange Nzihou $^{\mathrm{a}, *}$, Gilles Flamant $^{\mathrm{b}}$, Brian Stanmore ${ }^{\mathrm{c}}$ \\ ${ }^{a}$ Université de Toulouse, Mines Albi, CNRS, Centre RAPSODEE, Campus Jarlard, F-81013 Albi cedex 09, France \\ ${ }^{\mathrm{b}}$ Processes, Materials and Solar Energy Lab (PROMES-CNRS) 7, rue du Four Solaire, Odeillo, 66120 Font Romeu, France \\ ${ }^{\text {c } F o r m e r l y ~ o f ~ t h e ~ U n i v e r s i t y ~ o f ~ Q u e e n s l a n d, ~ B r i s b a n e ~ Q L D ~ 4072, ~ A u s t r a l i a ~}$
}

\begin{abstract}
A B S T R A C T
Biomass represents a renewable source for transport fuels when processed by gasification, followed by catalytic conversion of the syngas to liquids. The efficiency of biomass gasification can be improved by supplying process heat from concentrated solar systems, which can attain the required temperature of $900{ }^{\circ} \mathrm{C}$. Various chemical routes and contacting configurations are reviewed. The challenges related to biomass-based processes are discussed. Heat and material balances are then deduced. The area of land required for growing biomass can be reduced using the application of thermal solar to one half of that needed for a standard gasification system. If hydrogen is generated by solar means in order to reduce carbon dioxide emissions to zero, the figure becomes one third. Examples of the land requirements for three different biomass materials are presented.
\end{abstract}

Keywords:

Biomass

Gasification

Concentrated solar energy

Solar fuels

Environmental impact

\section{Introduction}

Modern industrial societies are driven by petroleum products in the form of refined fuels which are used in land, sea and air transport. A recent comprehensive survey of the likely worldwide depletion of petroleum resources was given by Nashawi [1], who predict that peak oil will occur in 2014/5. The consequent inexorable rise in liquid fuel prices requires a broadening of the resource base to include renewable energy sources. Various pathways for the production of hydrocarbon fuels from renewable have been discussed in the literature Graves [2]. Biomass is a logical candidate for this application, and its use is being vigorously pursued [3].

All biomass materials are a mixture of cellulose, hemi-cellulose and lignin. Cellulose, which comprises about half of the cell walls of plants, is a linear polysaccharide of $\beta$-D glucopyranose units linked with 1-4 glycosidic bonds:

$-\left\{\left[\mathrm{C}_{5} \mathrm{H}_{3}(\mathrm{OH})\left(\mathrm{CH}_{2} \mathrm{OH}\right) \mathrm{O}\right]-\mathrm{O}-\left[\mathrm{OC}_{5} \mathrm{H}_{3}(\mathrm{OH})\left(\mathrm{CH}_{2} \mathrm{OH}\right)\right]\right\}-$.

Hemicelluloses are polysaccharides of variable composition, including monosaccharide units with both five and six carbon members. Lignin is an irregular polymer consisting mainly of methoxy-phenylpropane units:

\footnotetext{
* Corresponding author. Tel.: +33 563493222; fax: +33 563493099

E-mail address: ange.nzihou@mines-albi.fr (A. Nzihou).
}

$-\left[\mathrm{C}_{6} \mathrm{H}_{4-\mathrm{n}}\left(\mathrm{OCH}_{3}\right)_{\mathrm{n}}-\mathrm{CH}=\mathrm{CH}-\mathrm{CH}_{2}\right]-$

In contrast to fossil fuels, all biomass components contain high percentages of oxygen, with cellulose containing about $50-52 \%$ oxygen and lignin $28-33 \%$ oxygen. Some examples are given in Table 1. The amount of inherent mineral matter present in biomass is low, but soil etc tends to be collected when harvesting agricultural wastes, especially during episodes of rain. Some biomass fuels from agricultural sources have high moisture contents in the field.

The traditional method of carrying out conversion to transport fuel in Brazil is via sugar cane, which is an excellent converter of solar radiation into biomass. In the USA the preferred source is corn. Studies on conversion of biomass to ethanol by fermentation have shown that the energy ratio i.e. the energy in the product ethanol to the energy equivalent used in its production (mostly as fossil fuels) is only slightly greater than unity in the USA [4].

An alternative technique for the production of liquid fuels from biomass is pyrolysis, whereby the feed is heated in the absence of oxygen in order to fracture some of the $\mathrm{C}-\mathrm{H}$ and other bonds, thus producing a range of products with smaller molecules, including tars and gases. The residual is a char comprised mostly of carbon, but containing much of the original mineral matter. Under extremely rapid heating (flash pyrolysis), significant amounts of hydrogen are produced from lignin [5].

Higher volatile yields are produced by flash pyrolysis conditions, which entail using small particle sizes to ensure rapid temperature 
Table 1

Typical biomass analyses.

\begin{tabular}{|c|c|c|c|c|c|c|c|c|}
\hline Property & Demol wood & Wood chips & Sewage sludge & Bag-asse & Wheat straw & Coffee Gr'nds & Straw & Almond shells \\
\hline Reference & $\mathrm{J}$ & $\mathrm{J}$ & Ing & $\mathrm{J}$ & $\mathrm{J}$ & $\mathrm{M}$ & $\mathrm{J}$ & $\mathrm{J}$ \\
\hline Moisture & 8 & 45 & $50-80$ & $45-55$ & & 10 & 14 & - \\
\hline Ash (db) & 13 & 1.0 & 30 & $2-6$ & 7 & 1.7 & 4.5 & 3.3 \\
\hline VM (db) & 75 & 81 & 61 & $75-88$ & 75 & 75 & 78 & 76 \\
\hline C & 53 & 50 & 51 & 52 & 48 & 54 & 47.5 & 51 \\
\hline $\mathrm{H}$ & 5.6 & 5.8 & 7 & 6.2 & 5.9 & 6.1 & 5.9 & 6.2 \\
\hline$S$ & 0.14 & 0.05 & 1 & 0.04 & 0.17 & 0.03 & 0.15 & 0.04 \\
\hline $\mathrm{N}$ & 0.66 & 0.3 & 5 & 0.16 & 0.47 & 2.9 & 0.7 & 0.79 \\
\hline $\mathrm{Cl}$ & 0.06 & 0.02 & 0.1 & 0.03 & 0.25 & & 0.4 & $<0.01$ \\
\hline K & 0.28 & 0.1 & & $<0.01$ & 1.8 & & 1.0 & 1.6 \\
\hline $\mathrm{O}$ & 39 & & 36 & 44 & 45 & 36 & & 42 \\
\hline $\mathrm{SE}$ (daf) $\left(\mathrm{MJ} \mathrm{kg}^{-1}\right)$ & 23 & 19.5 & 23.5 & 22 & 18 & 22 & 18.6 & 19.5 \\
\hline
\end{tabular}

$\mathrm{af}=\mathrm{as}$-fed; $\mathrm{db}=$ dry basis; daf = dry, ash-free; $\mathrm{VM}=$ volatile matter; $\mathrm{SE}=$ specific energy.

rise e.g. [6]. The contacting techniques which have been employed include entrainment flow, fluidised beds and cyclone reactors. Short residence times at elevated temperature mean that secondary cracking reactions of tars to gas are minimised. For biooil production it is claimed [7] that a mixture of gas - solid heat transfer and wall radiation will avoid the attrition losses caused by solid-solid collisions in fluidised beds.

Sewage sludge behaves in a similar manner to wood [8]. The biooil obtained from hardwood by conventional pyrolysis closely resembled residual of heavy fuel oil [9]. Although it appeared to be homogeneous, it was found to be microscopically composed of a tar-like, char-laden phase immersed within a bulk aqueous phase.

A disadvantage of the pyrolysis technique is the wide range of oxygenated products, many of which e.g. phenols, are difficult to treat in downstream processes. The pyrolysis oil can be upgraded into a liquid of adequate quality, but from a commercial pyrolysis operation the oil typically represents only $25 \%$ of the mass and $35 \%$ of the energy of the feed, see Table 2.

A second method for producing liquid fuels from biomass is gasification with steam and/or oxygen to give syngas $\left(\mathrm{CO}+\mathrm{H}_{2}\right)$, which can then be converted into liquid. It should be noted that pyrolysis of a wet biomass material would be a form of gasification, as any water present would enter into the reaction sequences. With very wet biomass, gasification in supercritical water i.e. at very high temperatures and pressures has been shown to be feasible [10].

For subsequent use, the ratio of $\mathrm{CO}$ to $\mathrm{H}_{2}$ in the syngas should ideally be near equimolar, as the hydrocarbons used as transport fuels contain about $16 \%$ hydrogen i.e. an empirical formula of $\mathrm{CH}_{2.1}$. However the Fischer-Tropsch (FT) process, which is the established technology to convert syngas into liquid hydrocarbons, is usually run with an excess of hydrogen over carbon monoxide.

Since the major gasification reactions in this process are endothermic, it is usual to introduce an oxidant (air, pure oxygen) in order to make the process autothermal at temperatures around $900{ }^{\circ} \mathrm{C}$. Of concern in conventional gasification is the introduction

Table 2

Mass/energy balance for the pyrolysis of forest waste [57].

\begin{tabular}{lccl}
\hline Component & Mass (\%) & Energy (\%) & Product SE $\left(\mathrm{MJ} \mathrm{kg}^{-1}\right)$ \\
\hline Input & & & \\
Pine bark/sawdust & 100 & 100 & 20.4 \\
Water & 49 & & \\
Output & & & \\
Char & 23 & 35 & $25.6-31.4$ \\
Oil & 25 & 35 & $23.3-30.2$ \\
Gas & 68 & 22 & $7.5-18^{\mathrm{a}}$ \\
Water & 33 & & \\
Losses & & 8 & \\
\hline
\end{tabular}

${ }^{\mathrm{a}} \mathrm{MJ} \mathrm{m}^{-3}$. of nitrogen into the gas stream if air is used as the oxidant. The commercial systems currently in operation e.g. SASOL on coal, therefore use pure oxygen, which introduces another drain on energy output. An alternative approach is to operate the gasification and combustion steps in separate vessels [11], thus producing separate streams of product syngas and flue gas.

In conventional process industries, heat supplied at the required temperature of $900{ }^{\circ} \mathrm{C}$ would be obtained from the combustion of a fossil fuel. Even if biomass is used in order to reduce $\mathrm{CO}_{2}$ emissions (internally or externally), it also reduces the amount of syngas produced from the cropping area. The energy balance across the system is a dominant concern, as some of the carbon in the feedstock is converted to carbon dioxide in order to sustain the gasification reactions.

The challenges being faced by biomass-based processes in reaching industrial scale have previously been summarised [12]. They include the emission of fouling and corroding pollutants formed from elements such as chlorine, sulphur and metals, the overall energy efficiency and the regulation of the industry. In regard to the latter, the policies in place have not kept pace with technological developments since the 1990s. Other concerns involve adequate models to guide the scale-up, flexibility and economic viability of the technologies. At the moment there is a lack of data on the availability and properties of current and potential biomass sources.

In gasification processes, oxygen is required only for supplying heat to the system by combustion. If an external heat source is available, steam alone is sufficient to gasify the feed. A supplementary source of high temperature energy would benefit the economics and lessen the environmental impact of biomass gasification. The enthalpy in the product syngas is greater than that of the fuel feed, often by a considerable amount e.g. $45 \%$ for coal [13]. Some researchers have proposed the use of nuclear energy for this purpose, but this introduces another set of environmental concerns.

A renewable option is high temperature heat from a concentrating solar collector. According to Z'Graggen [14], the advantages of using solar heating can be summarised in four categories.

1. The calorific value of the feedstock is upgraded.

2. The gaseous products are not contaminated by the by-products of combustion.

3. The discharge of pollutants to the environment is reduced.

4. The need for energy-intensive processing of pure oxygen is eliminated.

The application of solar power to syngas production involves the coupling of two distinct technologies, namely the production of high temperature solar heat and the gasification of biomass. It is the 
interface between these two comparatively well-researched technologies which offers the greatest challenge to the development of the concept. The state-of-the-art for these two technologies will be discussed, and then the approaches being taken to link the two.

\section{High temperature solar energy}

The intensity of solar radiation above the earth's atmosphere is around $1.4 \mathrm{~kW} \mathrm{~m}^{-2}$, whereas the average daily insolation (over $24 \mathrm{~h}$ ) at the surface is likely to be $200-400 \mathrm{~W} \mathrm{~m}^{-2}$, depending on the latitude. During the day the DNI (Direct Normal Irradiation) may reach $1000 \mathrm{~W} \mathrm{~m}^{-2}$. This is in equilibrium with the temperature of a black body near $360 \mathrm{~K}$ i.e. about $88{ }^{\circ} \mathrm{C}$ (stagnation temperature). On the other hand, a black body at a temperature at $900{ }^{\circ} \mathrm{C}$ will be in equilibrium with an incident radiation of $37 \mathrm{~kW} \mathrm{~m}^{-2}$. Therefore to act as a heat source for gasification, solar radiation will need to be concentrated theoretically by at least an order of 50 times, but much more than this in practice. It is claimed [15] that a concentration of 500 times is necessary for maximum process efficiency at about $900{ }^{\circ} \mathrm{C}$.

Among solar concentrating technologies, parabolic dishes and solar tower systems can reach the conditions necessary to gasify biomass. Since parabolic dishes are limited in size, for large scale thermal applications the solar tower system (also known as a heliostat field collector (HFT) or a central receiver system) is the most desirable approach. An array of slightly concave mirrors (heliostats) focuses the solar radiation onto an elevated central receiver (tower), where it is absorbed by a solar receiver-reactor. Radiation flux densities of $200-2000 \mathrm{~kW} \mathrm{~m}^{-2}$ have been achieved.

A recent study [16] presents information on heliostat layout design suitable for high temperature processing. The optical system incorporates a secondary reflector located at the top of the tower to re-transmit radiation from the heliostat field to the receiver. This increases the concentration ratio and decreases losses. Overall solar to solar-to-chemical energy conversion efficiencies are derived; they include optical efficiencies (heliostat field efficiency, intercept factor and secondary efficiencies) and receiver-reactor efficiency. For coal gasification, it was estimated that a $100 \mathrm{MW}$ solar plant operating at $1300 \mathrm{~K}$ reaches a $40 \%$ solar-to-chemical energy conversion efficiency.

Another option proposed for optical collection known as the beam-down system [17], places the receiver-reactor at ground level instead of on the tower. It makes use of three consecutive reflections from the heliostat field to two mirrors, with a hyperboloidal reflector at the top of the tower redirecting sunlight to a parabolic concentrator at ground level.

The heat transfer fluids which have been used include water/ steam when power generation is the purpose, and liquid sodium, oil or molten salt mixtures when storage is preferred. At the moment a molten nitrate salt mixture (sodium/potassium) appears to offer the best solution, due to its thermal stability, heat transfer properties, cost, toxicity etc. However, Hertwich [18] points out that such systems are limited to temperatures around $565^{\circ} \mathrm{C}$. Adoption of a mixture of fluorides $(\mathrm{Li} / \mathrm{Na} / \mathrm{K})$ could raise this to a level which is suitable to support gasification. The use of a fluidised suspension of particles as the heat transfer fluid was proposed in the 1980s [19].

One significant concern is the transient response of the system in following rapid changes in solar insolation. In most applications, including gasification, the temperature of the heat transfer fluid is the major variable to be controlled. This requires a rapid adjustment to the flowrate of fluid, so that the response characteristics of the thermal system must be well understood. A possible response to this constraint is the association of solar biomass gasification with a gas turbine burning the syngas to produce electricity as proposed by Buck at al. [20] for natural gas reforming. In this situation the produced syngas is a chemical storage of solar energy.

\section{The gasification of biomass}

Biomass is currently available in large quantities as waste from agriculture and forestry e.g. wood, straw, rice husks. If managed as an energy crop, it is claimed [3] that 1.38 billion tonnes dry weight of biomass could be produced in the USA without disturbing current agricultural and forest practices.

A summary of its application to energy production is given by Jenkins [21], for power generation by Bridgewater [11], and of its conversion to motor fuel via gasification by Zhang [22]. The composition of a range of biomass types is comparatively constant, Table 1, and contains around 50\% carbon, 6\% hydrogen and 40\% oxygen on a dry, ash-free basis. Its energy content on this basis (lower value) is around $19-20 \mathrm{MJ} \mathrm{kg}^{-1}$. Sewage sludge contains less oxygen and more hydrogen and nitrogen than natural biomass, so that it has a higher specific energy.

For calculation purposes in this review, an empirical 'mole' of biomass will be regarded as $\mathrm{CH}_{1.4} \mathrm{O}_{0.6}$, i.e. $\mathrm{C} \approx 52.2 \%, \mathrm{H} \approx 6.1 \%$, $\mathrm{O} \approx 41.8 \%$ on a mass basis. This 'compound' will have a standard heat of formation $\Delta \mathrm{H}_{\mathrm{o}}^{f}$ of $-117 \mathrm{~kJ} \mathrm{~mol}^{-1}\left(-27.8 \mathrm{kcal} \mathrm{mol}^{-1}\right)$, based on a lower specific energy of $19.5 \mathrm{MJ} \mathrm{kg}^{-1}$. When burned it would require $1.46 \mathrm{~kg}$ of oxygen per $\mathrm{kg}$ of dry fuel.

$$
\mathrm{CH}_{1.4} \mathrm{O}_{0.6}+1.05 \mathrm{O}_{2} \rightarrow \mathrm{CO}_{2}+0.7 \mathrm{H}_{2} \mathrm{O} \quad \Delta \mathrm{H}_{o}^{c}=-448 \mathrm{~kJ} \mathrm{~mol}^{-1}
$$

Note that other authors [3] have used $\mathrm{C}_{6} \mathrm{H}_{9} \mathrm{O}_{4}$ for the biomass molecule (or $\mathrm{CH}_{1.5} \mathrm{O}_{0.67}$, which is equivalent to $\mathrm{C} \approx 49.6 \%, \mathrm{H} \approx 6.2 \%$, $0 \approx 44.2 \%$.

Syngas is the name given to the mixture of carbon monoxide and hydrogen which is produced when a carbohydrate (biomass) such as wood or straw is reacted with a gasifying agent e.g. carbon dioxide or steam. The optimum temperature for the reaction is given as $900{ }^{\circ} \mathrm{C}$ [23]. It must be cleaned to remove impurities, and may be treated to change the $\mathrm{CO} / \mathrm{H}_{2}$ balance, or to remove $\mathrm{CO}_{2}$.

The cleaned syngas can be reacted in either of two ways to give transport fuel. One commercial approach is reaction over a Fischer-Tropsch catalyst to produce a range of hydrocarbons which can be tailored as transport fuels. The process is currently carried out on a large scale with a coal feed by SASOL in South Africa. The FT process is a mature technology and will determine the manner in which the gasification process is configured, especially in connection with energy consumption.

A second approach is to use the gas as feed for alcohol production e.g. methanol via condensation over a catalyst. For this application the $\mathrm{CO} / \mathrm{H}_{2}$ ratio must be 0.5 . An alternative is to use it as a nutrient for biological processing by fermentation to give alcohols e.g. Koskata [24]. This route is under development, so that little information is available.

In an equilibrium situation during gasification, all of the oxygen present in biomass will be incorporated into the syngas as CO. A theoretical calculation by Melchior $[25,26]$ for a char made from beechwood indicates that an empirical 'mole' of this material $\left(\mathrm{CH}_{0.418} \mathrm{O}_{0.117} \mathrm{~S}_{0.0003} \mathrm{~N}_{0.006}\right)$ would need $0.883 \mathrm{~mol}$ of steam to produce a mixture of $\mathrm{CO}$ and $\mathrm{H}_{2}$ only. The required temperature for complete conversion is in the vicinity of $1200 \mathrm{~K}\left(927^{\circ} \mathrm{C}\right)$. Under these conditions the gas composition is $51 \% \mathrm{H}_{2}$ and $46 \% \mathrm{CO}$ by volume. The energy requirement is $160 \mathrm{~kJ}$ per mole of carbon, which is equivalent to $11.2 \mathrm{MJ}$ per $\mathrm{kg}$ of dry wood.

A similar equilibrium calculation for pure carbon is presented by Kodama, for both atmospheric and 20 bar conditions. The results are presented in Fig. 1, where $1200 \mathrm{~K}$ is again required for complete conversion at 1 bar, but $1500 \mathrm{~K}$ for the higher pressure. The syngas components are present in equal amounts, while the higher pressure favours the formation of methane. A study on the steam 

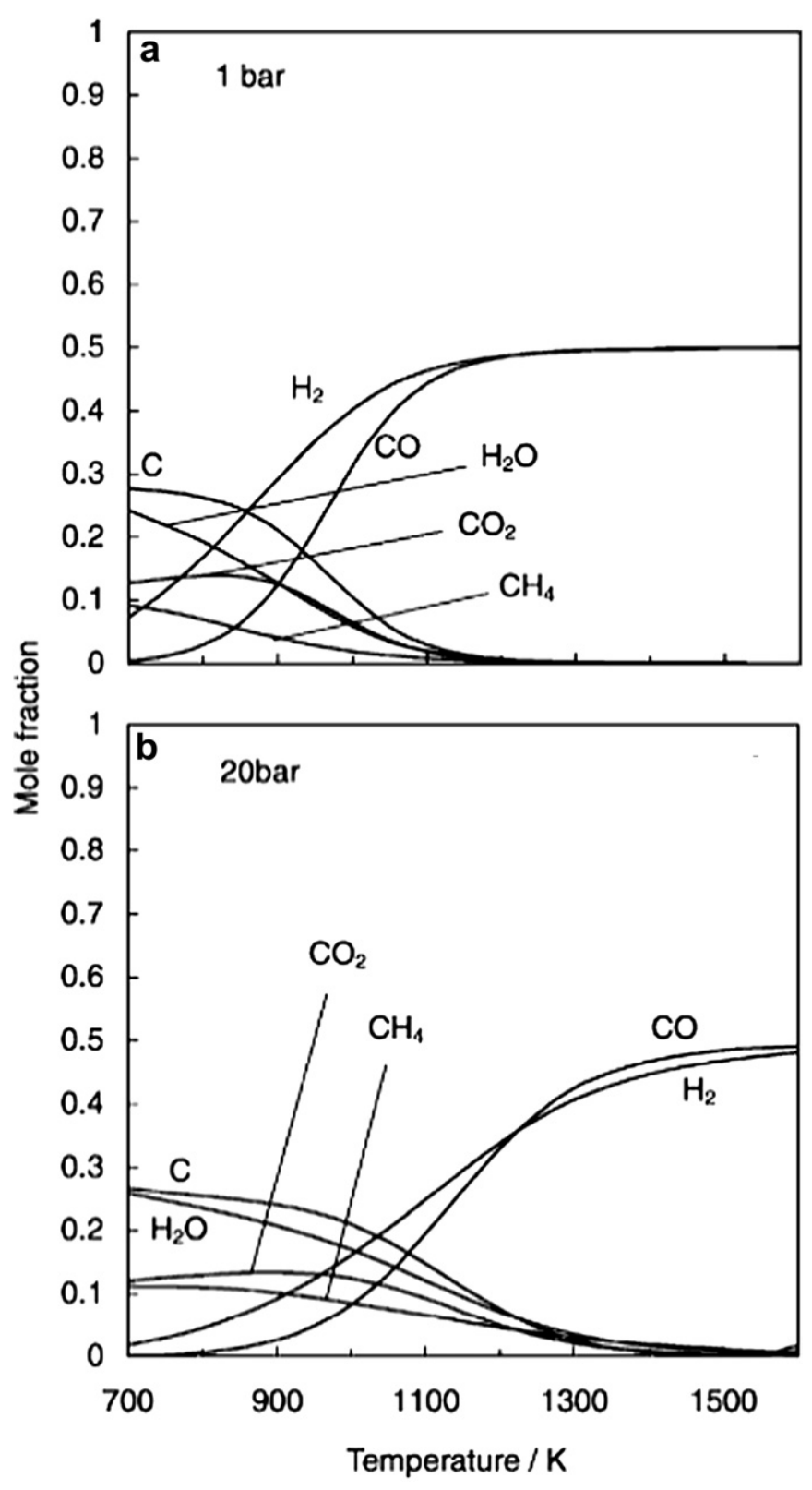

Fig. 1. Thermodynamic equilibrium calculation for carbon and steam [13].

gasification of almond shells in a fluidised bed by Rapagnà found that there was little change in the gas-to-char ratio when the steam-to-biomass ratio was varied between 0.5 and 1 .

A material balance such as Equation (2) below for a typical biomass from Table $1\left(\mathrm{CH}_{1.4} \mathrm{O}_{0.6}\right)$ shows that a steam addition of about $30 \%$ of its mass would be required for complete conversion, with a product $\mathrm{CO} / \mathrm{H}_{2}$ ratio similar to that above. In practice, the natural moisture content of the biomass could supply the water, but some of the feed would be lost as tars before it could be converted. Assuming complete conversion:

$\mathrm{CH}_{1.4} \mathrm{O}_{0.6}+0.4 \mathrm{H}_{2} \mathrm{O} \rightarrow \mathrm{CO}+1.1 \mathrm{H}_{2} \quad \Delta \mathrm{H}_{0}^{f}=+104 \mathrm{~kJ} \mathrm{~mol}^{-1}$

The energy needed to drive this reaction is $+104 \mathrm{~kJ} \mathrm{~mol}^{-1}$, or only 4.5 MJ per kg of dry material, which is far less than the wood char mentioned above. The ratio of $\mathrm{CO} / \mathrm{H}_{2}$ can be tailored to suit the application by means of the water-gas shift reaction, where the carbon monoxide can be used to reduce steam to hydrogen:

$\mathrm{CO}+\mathrm{H}_{2} \mathrm{O} \rightarrow \mathrm{CO}_{2}+\mathrm{H}_{2}-42 \mathrm{~kJ} \mathrm{~mol}^{-1}$

With a biomass fuel, there are a number of disadvantages inherent in the nature of the material. The density of the feed material is low, so that the throughput is lower and feeding difficulties are experienced with the fibrous mass. The efficiency of gasification processes is thermodynamically favoured by high pressures, but operating in this mode would exacerbate feeding problems.

The process uses biomass with a gasifying medium and energy to produce a syngas, but also significant amounts of tar, as well as hydrogen sulphide, ammonia, hydrogen chloride and a residual solid char. The SASOL installations use pressurised, moving bed Lurgi gasifiers which are unsuitable for small irregular particles of biomass. For large scale operations with this type of feed material, fluidised bed gasifiers have generally been chosen [27-29]. The fluidised bed system ensures good gas-solid contacting, easy recycle of char, stable operation and good heat transfer properties. In these respects it is superior to packed bed operation [30].

As noted above, a major difficulty with the gasification of biomass is the formation of tars and other contaminants [23,31,32] which must be removed before the gas can be used in subsequent processes. Rabou [32] report that $10 \mathrm{~g}$ of tar can be expected in every $\mathrm{Nm}^{3}$ of gas coming from a fluidised bed gasifier. This would represent about $5 \%$ of the mass of the original biomass if Equation (2) applies. The composition of some of the higher-boiling tars formed at different temperatures are shown in Fig. 2 [32] The material is rich in phenols, and multi-ring compounds are prevalent. The usual way of removing tar is by catalytic conditioning [33].

Our knowledge of the tar content of syngas from gasifiers has been gained from systems fed with oxygen to satisfy the thermal requirements. This oxygen also attacks the tars, so that a system without free oxygen such as envisaged in the current application will probably contain more tars than the oxy-system. All of the above will lower the energy output and hence the financial feasibility of gasifying biomass in comparison to gasifying bulk carbon in the form of coke or coal.

When a carbonaceous fuel is introduced into a heated reactor, the initial process is pyrolysis, even when a gasifying agent such as steam is present. The primary products are those which would be produced from a simple thermal treatment. For example, a lab scale investigation of the steam gasification of biomass in the form of

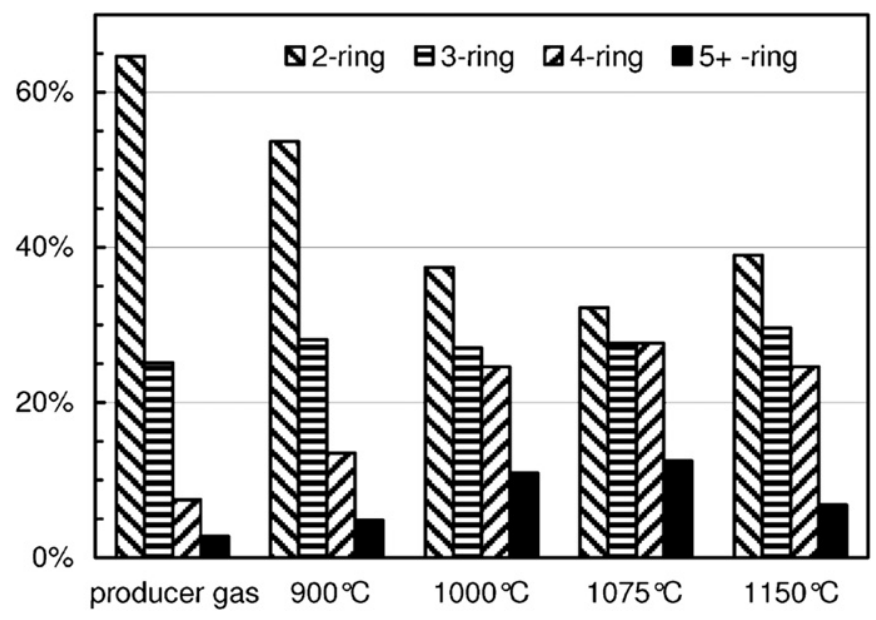

Fig. 2. Multi-ring tar components formed during the gasification of biomass [32]. 
coffee grounds [29] found that most of the gas was generated from volatile materials. About $3 \%$ of the dry mass was evolved as tars, and $22 \%$ remained as char after $160 \mathrm{~s}$ of reaction time. In this period there was $75 \%$ conversion of carbon.

It has been shown that the initial product of lignin and cellulose subjected to intense radiation of over $1 \mathrm{MW} \mathrm{m}^{-2}$ is a short-lived liquid intermediate $[34,35]$. The liquid is solid at room temperature, is soluble in water, and when subjected to further pyrolysis produces gases, tars and some char. The products from the irradiation of cellulose [36] are similar to those of lignin [5].

A series of studies by Lédé and associates [37-40] used a heated cyclone reactor to carry out pyrolysis and gasification of different types of biomass. The biomass particles are conveyed into the cyclone in a gas stream, strike the hot walls and react. The residual solids are removed from the bottom of the cyclone, while the gas, which contains the volatile products, leaves via the vortex finder. The system is called 'ablative' pyrolysis, because the heat transfer and reaction are much faster than heat conduction through the solid. The reactions occur in a thin layer at the surface, and steep temperature gradients are formed. The gaseous products from a cyclone reactor have very short residence times so that secondary cracking reactions are minimised.

What was referred to as flash pyrolysis on beechwood sawdust was carried out in the presence of steam. Because the steam amounted to 3-12 times the mass flowrate of the dry biomass, it could be better considered as gasification. A noble gas was used as a carrier, but subsequent tests used recycle product gas. Even though the reactants reached an exit temperature of only $500-600{ }^{\circ} \mathrm{C}$, it was found that the overwhelming amount of product was gaseous (80\%) and tars (15\%), with only $4 \%$ of the feed emerging as char. A small amount of aerosol was also produced.

The dry product gas consisted of about $25 \% \mathrm{H}_{2}, 45 \% \mathrm{CO}, 10 \% \mathrm{CO}_{2}$, $10 \% \mathrm{CH}_{4}$ and another $10 \%$ of higher hydrocarbons. As a result the $\mathrm{SE}$ of the gas was around $18 \mathrm{MJ} \mathrm{Nm}^{-3}$. No indication of the properties of the liquids was given. However, the oil properties are reported in another paper [39], where conditions were optimised for bio-oil production. Accordingly the cyclone wall temperatures were kept low, and steam was not added, so that the liquids represented $74 \%$ of the dry biomass. However the heavy oil contained 35\% oxygen and the light oil $62 \%$.
The thermal cracking of biomass-derived vapours has been measured for a number of conditions [41,42]. For temperatures between 836 and $1303 \mathrm{~K}$, and residence times from 0.3 to $0.5 \mathrm{~s}$, the Arrhenius kinetic constants of $59 \mathrm{~kJ} \mathrm{~mol}^{-1}$ activation energy and $1930 \mathrm{~s}^{-1}$ pre-exponential factor for wood were in good agreement with those reported by other authors.

\section{Application of solar energy to thermal gasifiers}

Engineering a commercial solar gasification installation is in effect the undertaking of a marriage between a clean, sometimes intermittent energy source with a 'dirty' chemical process which requires constant operating conditions for optimum performance. Achieving this linkage offers the greatest challenge to proving and commercialising the technology. The major challenge on a large scale is the interface between the high temperature radiation and a diffuse assembly of biomass particles. Heat transfer, including radiation, is a surface phenomenon so that large contact areas are necessarily involved. Configuring this contact is the subject of much of the research into solar gasification.

Three types of contacting between the solar radiation and the biomass/steam reactants have been proposed.

1. Direct heating through a transparent window, where the heating occurs as the radiation strikes the actual reactants

2. Indirect heating through an intermediate 'emitter' surface to expose the solid/gas flow to a larger radiative area, and also to separate the steps

3. Heating via a transfer fluid such as a molten salt, a supercritical fluid or a gas emulsion of sand or other mineral particles.

Option 1. Many of the experimental trials of the technology have used direct heating in small reactors fed with pulverised biomass in entrainment flow and with a transparent window to admit radiation e.g. Kodama [13], Z'Graggen [14], Gordillo [43,44], Steinfeld [45]. A typical example of the reactors used is shown as Fig. 3 [45]. These have inevitably been on a small scale, and scaling up would take the form of banks of multiple reactors. The short residence times which have been shown to suffice, of the order of a tenth of a second [26], assist in maintaining throughputs.

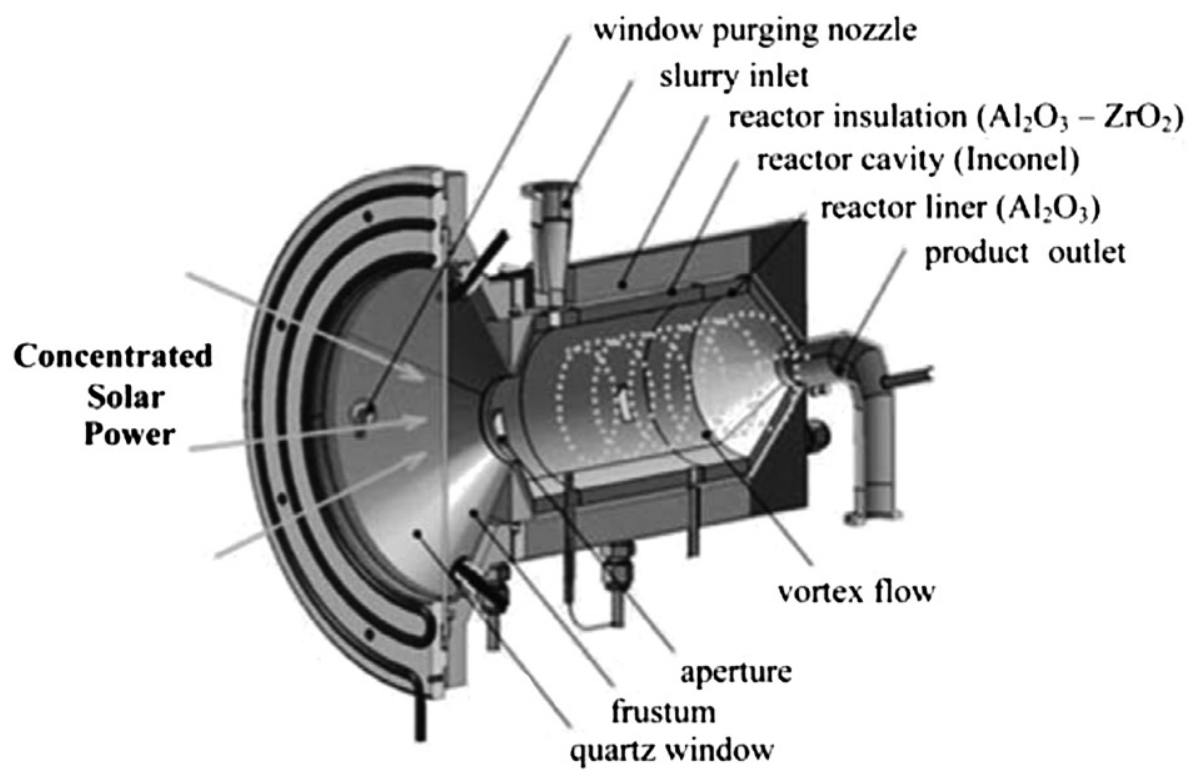

Fig. 3. Concentrated solar reactor configurations for gasifying biomass char [45]. 
Cellulose is a highly reflecting and weakly absorbing (semitransparent) material with regard to infrared radiation [34,35]. Thus only a small fraction of any incoming flux will be absorbed. It undergoes softening and some agglomeration between contacting particles.

When beechwood cylinders $40 \mathrm{~mm}$ in diameter were irradiated at $25-80 \mathrm{~kW} \mathrm{~m}^{-2}$, the fraction of char product fell from 45 to $20 \%$ as the intensity of irradiation increased [46]. The liquid yield amounted to $55 \%$ and the gas yield increased slowly from 10 to $20 \%$.

One aspect which requires close consideration in direct systems is the need to keep the window clean from tars and thus able to continue to pass the radiation. The steps being taken to prevent tar deposition include careful design of the aerodynamics of the feed flow, and sweeping the surface of the window with a clean gas stream. An advantage of entrainment gasification is that it leads to lower tar formation [32].

Option 2. An indirect approach by means of an emitter plate has been adopted on a research scale by the ETH-PSI group in Switzerland. The plate is heated by concentrated radiation, and then reradiates the energy into the reaction system. Steam gasification of biomass char, regarded as comprising only carbon, was modelled for downdraft and fluidised bed gasifiers [43,44]. The energy was applied by irradiating the top of the bed via the emitter plate. This produced poor results with the fluidised bed, as the heat transfer into the bed was low. Better results were obtained with the downdraft configuration of a packed bed.

A possible commercial configuration would involve a parallel array of tubes containing the biomass particles in entrainment flow $[47,48]$, which would give good heat transfer characteristics. One option is that shown in Fig. 4, where the lift pipe is part of a fluid bed installation, and is transporting bed material and char. The problem of shielding would hinder a large assembly being employed.

A better 'emitter surface' configuration is the cyclone reactor as developed by Lédé and associates [37-40]. A battery of cyclones would constitute the target for the concentrated solar radiation. Wall

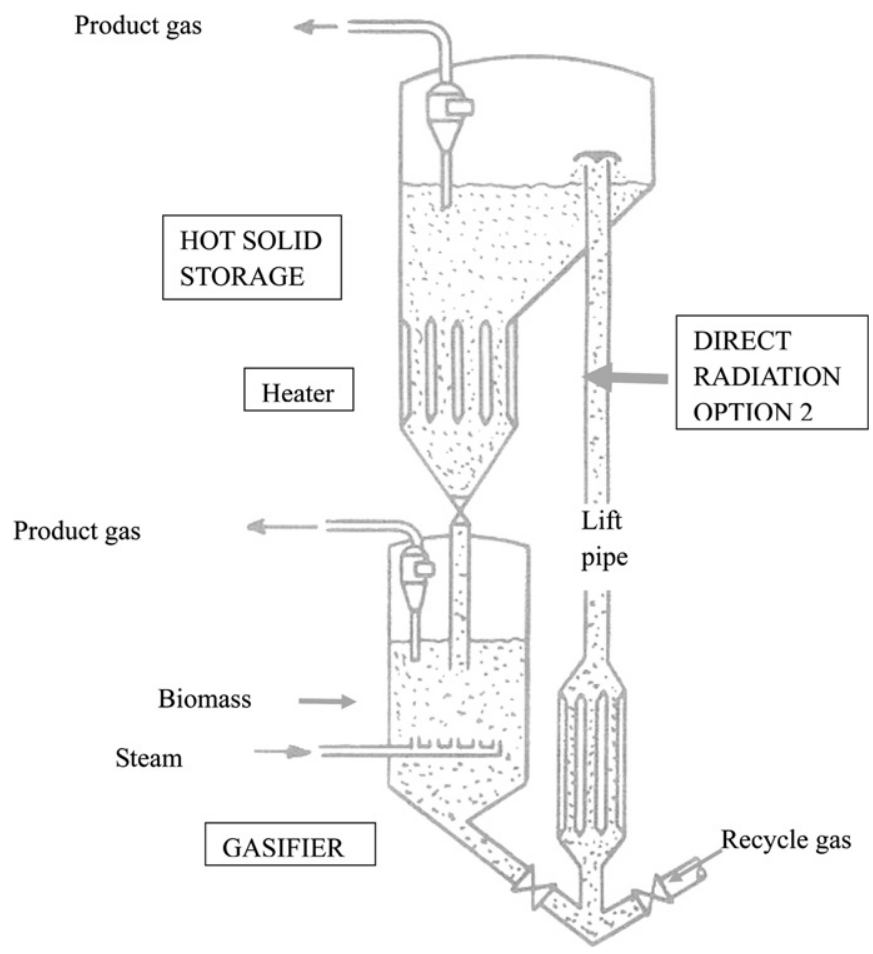

Fig. 4. Possible process configuration for a fluidised bed using an intermediate heating fluid. temperatures in the range of $900-1000{ }^{\circ} \mathrm{C}$ have been measured, although the exit gas temperatures, and thus the reaction temperatures, are much lower than this. The installation would be compact as the reaction and separation steps are performed in the one vessel. The capacity of cyclone reactors, based on heated wall surface area, is claimed to be over $30 \mathrm{~kg} \mathrm{~m}^{-2} \mathrm{~h}^{-1}$.

Option 3. The adoption of an intermediate transfer fluid improves operating flexibility and enables a wider range of contacting configurations to be utilised. The surface areas involved are no longer dictated overwhelmingly by the particle surface, but can be dispersed through the volume of a bed. An intermediate storage also smoothes out the intermittent supply of solar energy. Three configurations have been proposed.

Configuration 1, molten salt. The heat transfer fluid can be heated and stored at 'hot' conditions above the reactor working temperature as is conventionally used for HFT systems. It can then be sent to the reaction bed where the gasification process takes place. The spent fluid would then be sent to the 'cold' storage tank for subsequent reheating. A temperature drop of $100-150{ }^{\circ} \mathrm{C}$ could be envisaged. The pyrolysis/gasification of cellulose was studied by Adinberg in the temperature range 1073-1188 K using molten carbonates of sodium and potassium. About 94\% of the initial biomass was converted to syngas at $1123 \mathrm{~K}$, rising to $98 \%$ at $1188 \mathrm{~K}$, thus demonstrating the selectivity of this process towards gas production. The main gaseous components at $1188 \mathrm{~K}$ were hydrogen $(26 \% \mathrm{v} / \mathrm{v})$ and carbon dioxide.

Configuration 2, supercritical water. Gasification of biomass in supercritical water (SCW) could be a sound option when the biomass has a high moisture content, above 35\% [10,49-51]. By heating water to a temperature above its critical temperature $(647 \mathrm{~K})$ and compressing it to a pressure above its critical pressure (22 MPa), biomass is rapidly decomposed (within a few minutes) at high efficiency into a range of small molecules or gases. Supercritical water gasification (SCWG) is therefore a promising process to gasify biomass. In recent years, extensive research has been carried out to evaluate the suitability of various wet biomass gasification processes under SCW conditions. Although the work has been mostly on a laboratory scale and is still in the early developmental stage, the technology has already shown its economic competitiveness with other hydrogen production methods. Spritzer and Hong [48] have estimated the cost of hydrogen production produced by SCWG to be about US $\$ 3 / \mathrm{GJ}$ (US\$0.35/ $\mathrm{kg}$ ).

Configuration 3, gas-solid suspension. The good heat transfer characteristics of fluidised beds would allow the solar heat transfer fluid to be introduced into a jacket around the vessel, and also through tubes inside the bed. The bed is usually composed of sand, ash and char particles which are returned to the bed by a cyclone when they are blown from the reactor. Alternatively, the bed could be formed from particles of dolomite or olivine, natural minerals which are known to suppress tar formation [52].

The fluidised bed approach should be capable of scale-up, as combustion units of greater than $400 \mathrm{MW}_{\mathrm{e}}$ are currently in service. A diagram of a fluidised bed reactor with a heated lift tube and internal heat transfer tubes is given as Fig. 4. The system includes the storage of hot solid to allow the installation of large areas of heat transfer surface.

There is considerable erosion of in-bed tubes, so that the design of the heat transfer surfaces would need to carefully considered. In addition, although the mineral matter content of biomass is small, it contains significant amounts of potassium and chlorine, which produce low melting point ash, especially under reducing conditions. The problem of the fouling of heat transfer surfaces would need to be addressed.

One heat transfer device being promoted for this application is the high temperature heat pipe [10]. It offers a high thermal 
conductivity by means of two-phase liquid flow driven by evaporation and gravity/capillary circulation. It is reliable, efficient and automatically adjusts for heat flux. In order to operate at the required temperature, the working fluid would be a liquid metal such as sodium or potassium, or a mixture of the two.

It should be noted that an alternative route to syngas which involves an intermediate step is the option of using the solar heat to generate electrical power which can then be used to gasify the biomass under plasma conditions. The plasma is generated from a gas e.g. air, at high voltages between two electrodes. Plasma gasification is emerging as a viable technology, and is commercial in a number of plants processing wastes [53]. The main advantage of using this less energy-efficient process (the solar energy-toelectricity efficiency of $\sim 20 \%$ ) would be the high temperatures involved $\left(>2000^{\circ} \mathrm{C}\right)$. At these temperatures the product is exclusively gaseous, tar formation is negligible and the gas cleaning process is greatly simplified.

A survey of the thermal performance of plasma gasification by Baidoo [54] suggests that, depending on the relative amounts of product, overall efficiencies somewhat greater than those for conventional gasification can be realised. This would go some way towards ameliorating the poor efficiencies inherent in the heat engine cycle used to convert the solar heat into electrical energy.

\section{Efficiency and resource analysis}

The energy benefit of producing ethanol from biomass by fermentation has generated disputes because of the different bases used for analysis e.g. Engelhaupt [55]. In order to be realistic, all inputs need to be included, such as fertiliser application, transport, separation and purification. As noted above, the consensus seems to be that the energy ratio is slightly greater than unity in the USA. The ratio is more favourable in Brazil, namely 1.8 Barker [56], probably because cane is a high-yield crop, and there is considerable manual handling involved.

The pyrolysis of biomass for liquid production has been extensively examined e.g. Mohan [57]. They quote an energy balance, which is reproduced as Table 2, for the pyrolysis of forest waste in the form of a mixture of pine bark and sawdust as a typical process scenario. The energy which appears in the product oil represents only $35 \%$ of the energy in the feed. The char can be used as a soil remediator or burned to generate heat, while the gas can be used to drive the pyrolysis process. Because only part of the carbon in the feed is converted into product, the process will not respond as well to the use of an external heat source as will gasification. With a limited possibility for the application of solar energy, it will therefore not be further considered.

When considering the gasification route, the overall efficiency depends on the way in which the process is specified. Efficiency of steam raising and processing such as the water-gas shift reaction must be taken into account. In order to estimate the possible savings brought about by solar input, a full process configuration is required. For example, the simplified gasification flowsheet shown in Fig. 5 was presented by Hertwich [18] for the analysis of solar biomass gasification supported by an FT plant and the generation of hydrogen from water by solar energy.

The FT process, which can be described simply by two reactions [58]

$\mathrm{CO}+2 \mathrm{H}_{2} \rightarrow-\mathrm{CH}_{2}-+\mathrm{H}_{2} \mathrm{O}$

and

$2 \mathrm{CO}+\mathrm{H}_{2} \rightarrow-\mathrm{CH}_{2}-+\mathrm{CO}_{2}$

is generally run with an excess of hydrogen in the feed. The overall process is exothermic and may release around 30\% of the combustion heat of the biomass [3]. If the incremental $\Delta \mathrm{H}_{\mathrm{o}}^{f}$ of the $-\mathrm{CH}_{2}-$ unit in the motor fuel range is taken as $-25 \mathrm{~kJ} \mathrm{~mol}^{-1}$ $\left(\Delta \mathrm{H}_{\mathrm{o}}^{\mathrm{c}}=43.8 \mathrm{MJ} \mathrm{kg}{ }^{-1}\right)$, the reaction energies for Equations (4) and (5) are $\Delta \mathrm{H}_{\mathrm{o}}^{f}=-157$ and $-201 \mathrm{~kJ} \mathrm{~mol}^{-1}$ respectively.

Dietenberger notes that "current commercial FTS catalysts are known to provide $\sim 80 \%$ conversion of the CO to synfuel, although recent literature shows multistage strategies and new catalyst developments to boost conversion efficiencies and selectivity and overcome short deactivation times and excessive attrition rates".

As far as the actual conversion is concerned, the input of solar energy could replace that generated from combustion, Eq (1). A balance according to Eq. (2) indicates that $18.8 \%$ of a biomass feed is theoretically required to drive the gasification of the other $81.2 \%$. This is a minimum amount which can be saved with external heating of a standard gasifier.

It is instructive to examine the conversion limits of possible routes by a simple thermochemical analysis. A combination of Equations (2), (3) and (5) i.e. gasification followed by water-gas shift and FT gives a theoretical conversion to hydrocarbons and carbon dioxide:

$\mathrm{CH}_{1.4} \mathrm{O}_{0.6} \rightarrow 0.7-\mathrm{CH}_{2}-+0.3 \mathrm{CO}_{2} \Delta \mathrm{H}_{o}^{f}=-19.3 \mathrm{~kJ} \mathrm{~mol}^{-1}$

The result is an overall slightly exothermic system, which suggests that high thermal efficiencies should be achievable in an integrated plant if heat recovery from the exothermic water-gas

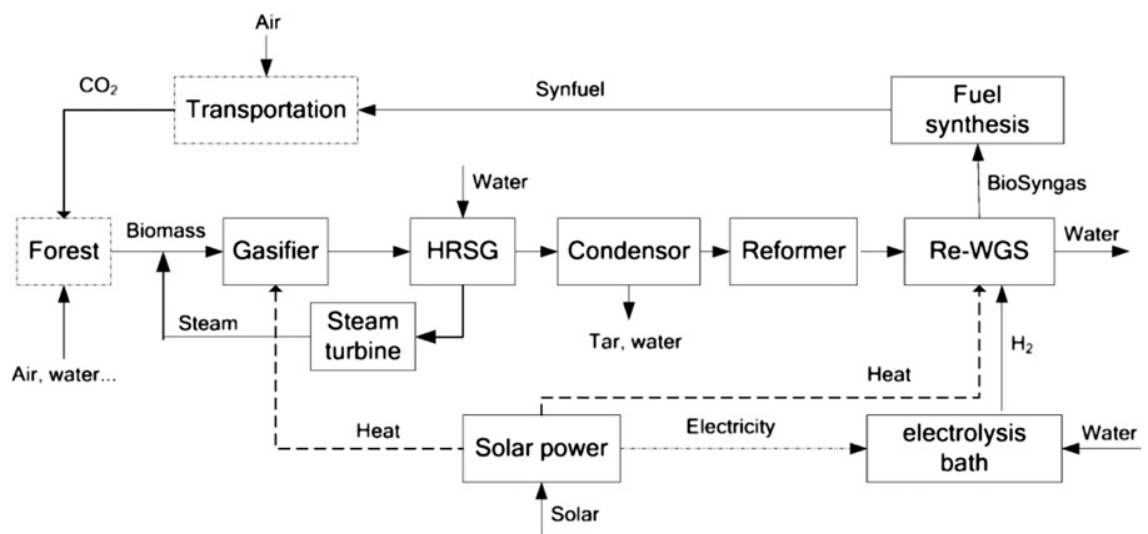

Schema of Scenario I: Synfuel synthesis through solar-driven biomass gasification.

Fig. 5. Flowsheet for the solar/gasification methanol plant proposed by Hertwich [18]. 
shift and FT reactions is possible. The water-gas shift reaction is carried out at temperatures of $200-350{ }^{\circ} \mathrm{C}$, while the heat from the FT process is available at $230-300{ }^{\circ} \mathrm{C}$. Both could be used in process heat exchange and for steam generation, but another high temperature source would be required.

In addition, under this regime the demand for water should be minimised, as there is no net consumption in the process. The inherent moisture of the feed material may be sufficient in practice to sustain the operation. The theoretical energy efficiency, defined here as the ratio of the energy in the product to that in the biomass is $96 \%$. A major disadvantage is that even if external heat is available, $30 \%$ of the feed carbon is lost as carbon dioxide, representing $1.15 \mathrm{~kg} \mathrm{CO}_{2}$ per $\mathrm{kg}$ fuel produced, or $26 \mathrm{~kg} \mathrm{GJ}{ }_{\text {fuel. }}^{-1}$.

On the other hand, if it is desired to eliminate carbon dioxide emissions entirely by considering that Equations (2) and (4) apply, and also using hydrogen made available by independent generation from water

$$
\mathrm{H}_{2} \mathrm{O} \rightarrow \mathrm{H}_{2}+0.5 \mathrm{O}_{2} \quad \Delta \mathrm{H}_{o}^{r}=+242 \mathrm{~kJ} \mathrm{~mol}^{-1}
$$

then:

$$
\begin{gathered}
\mathrm{CH}_{1.4} \mathrm{O}_{0.6}+0.3 \mathrm{H}_{2} \mathrm{O} \rightarrow-\mathrm{CH}_{2}-+0.45 \mathrm{O}_{2} \\
\Delta \mathrm{H}_{0}^{f}=+70 \mathrm{~kJ} \mathrm{~mol}^{-1}
\end{gathered}
$$

The overall reaction is endothermic, but the total energy demand would be even larger because of the need to dissociate $0.9 \mathrm{~mol}$ of water, representing $218 \mathrm{~kJ}$ molbiomass. The electricity for water electrolysis could be supplied from a solar source, but large quantities of water would be required. At a minimum, the water demand is $705 \mathrm{~kg}$ per tonne of dry tonne of biomass treated. The main energy load would be from the hydrogen plant, so it appears that there would need to be a trade-off between energy consumption, water use and carbon dioxide emissions. The theoretical energy efficiency in this case is $137 \%$, as solar energy has been incorporated into the product. This means that $37 \%$ of the energy stored in the product is thermal solar energy.

The theoretical volume of motor fuel which can be obtained from a tonne of dry biomass can be obtained by assuming that the carbon in the biomass is entirely converted into hydrocarbons i.e. Reaction (4) applies. A calculation based on an isooctane $\mathrm{C}_{8} \mathrm{H}_{18}$ product for petrol and $\mathrm{C}_{15} \mathrm{H}_{32}$ for diesel, with the densities of the two products taken as 700 and $770 \mathrm{~kg} \mathrm{~m}^{-3}$ respectively, gives $\sim 880 \mathrm{~L}$ per tonne of dry biomass for petrol and $\sim 800 \mathrm{~L}$ for diesel.

The practical application of these technologies has been examined in some detail by Hertwich [18] and Dietenberger [3], using conventional process flowsheeting. In the analyses, the figure used for biomass yield during agriculture is a matter of substantial consequence. These two major studies take the figure as $2.5 \mathrm{~kg} \mathrm{~m}^{-2} \mathrm{yr}^{-1}$ i.e. 25 tonnes $\mathrm{ha}^{-1} \mathrm{yr}^{-1}$, which is claimed for the farming of switchgrass. Since biomass has a dry, ash-free energy content of $19.5 \mathrm{MJ} \mathrm{kg}^{-1}$, this indicates an energy capture of $490 \mathrm{GJ} \mathrm{ha}^{-1} \mathrm{yr}^{-1}$. If the solar radiation is taken as $300 \mathrm{~W} \mathrm{~m}^{-2}$ daily mean, it represents a capture efficiency of $0.5 \%$. Sugar cane is commonly regarded as capturing $2 \%$ [59].

The switchgrass yield of $25 \mathrm{tha}^{-1} \mathrm{pa}$ is in the middle of the range obtained from various forms of cropping. It is native to North America, and produces high yields of cellulose with little application of fertilizer in rainfall areas from 380 to $750 \mathrm{~mm}$ pa [60]. However it should be noted that yields of only 5.2 to $11.1 \mathrm{t} \mathrm{ha}^{-1} \mathrm{pa}$ are quoted by Biello [61] for mid-west sites in the USA. Vamvuka [62] found yields of dry biomass between 15 and $24 \mathrm{tha}^{-1} \mathrm{yr}^{-1}$ over the second and third years of cultivation. Other reports vary widely depending on conditions (McLaughlin [63], West [64]), so that a figure of $18 \mathrm{tha} \mathrm{h}^{-1}$ was adopted for calculations. An evaluation of the ecological effects of switchgrass farming has been conducted [65].

Intensively farmed high-yield species e.g. sugar cane can give over 80 and up to $100 \mathrm{t} \mathrm{ha}^{-1} \mathrm{yr}^{-1}$ [56], which is presumably an asharvested yield. Dry matter yields are more likely to be around 40 to $45 \mathrm{t} \mathrm{ha}^{-1}$.

Semi-arid crops give far less. The yield of a native Eucalyptus globulis, Eucalyptus occidentalis and also Pinus radiata in semi-arid Australia is estimated by Sochacki [66] at 4 tonnes per hectare per year over a 3 year cycle. An alternative native Australian plant, the mallee bush, can give up to 20 green tonnes per hectare per annum without irrigation [67]. At $45 \%$ moisture, this is equivalent to $11 \mathrm{tha}^{-1}$ pa of dry biomass.

All of these species can be grown in rainfall areas of $300-600 \mathrm{~mm}$ pa, and the energy ratio for dry biomass production is estimated to be $>40$ for mallee. Mallee has the added advantage of being a salt-tolerant plant being used to remediate land affected by dry salinity, so that it can be grown in nonagricultural regions. Faced with the need for increasing food production, it is likely that only low value land will be available for energy crops; the competition for land will be a major concern needing resolution.

The study by Hertwich [18] compared three technologies, namely I. solar driven gasification with solar hydrogen to give methanol, II. conventional gasification producing methanol, and III. a coal-to-liquids plant, via the gasification/FT route. The proposal employs solar-generated hydrogen for the reverse water-gas shift reaction to upgrade the syngas by adjusting the $\mathrm{CO} / \mathrm{H}_{2}$ ratio. Any carbon dioxide present would be reduced to the monoxide, thus increasing the amount of recoverable carbon. The hydrogen could be produced by either the electrolysis of water, or its high temperature thermolysis.

The results are given below for the production of methanol, based on a dry biomass yield of $25 \mathrm{tha}^{-1} \mathrm{yr}^{-1}$. The automotive industry is comfortable with the adoption of methanol as a standalone fuel $[18,68]$ (Table 3 ).

This analysis predicts that conventional gasification would operate at $42 \%$ efficiency, whereas the application of external heat raises this to $60.9 \%$ i.e. a $45 \%$ increase in energy conversion. Both of these are approximately 0.45 of the theoretical maximum estimated above. It is clear that the solar alternative is better on both environmental (land use and $\mathrm{CO}_{2}$ emissions) and economic grounds.

A similar comprehensive analysis of four technologies which includes enhanced processing with hydrogen to convert all carbon to fuel was produced by Dietenberger [3]. The analysis predicts that four variations of the gasification route will produce various volumes of product in litres of motor fuel per dry tonne of biomass. The current circulating fluidised bed (CFB) route envisages recovering water from the flue gas in order to balance the water budget. Improved gasification technology accounts for the self-sufficient mode, and external (solar) heat describes the third. Finally an external source of hydrogen is involved.

Table 3

Evaluation of methanol production from biomass [18].

\begin{tabular}{llll}
\hline & Solar gasif & Gasif & Coal liquids \\
\hline Energy conversion efficiency (\%) & 60.9 & 42.0 & 36.5 \\
Fuel productivity $\left(\mathrm{kg} 100 \mathrm{~kg}_{\text {feed }}^{-1}\right)$ & 121 & 39.9 & 62.2 \\
Land use for biomass $\left(\mathrm{m}^{2} \mathrm{t}_{\text {fuel }}^{-1} \mathrm{yr}^{-1}\right)$ & 331 & 1003 & 0 \\
Land use for energy $\left(\mathrm{m}^{2} \mathrm{t}_{\text {fuel }}^{-1} \mathrm{yr}^{-1}\right)$ & 51.5 & 0 & 0 \\
Carbon dioxide release $\left(\mathrm{kg} \mathrm{GJ}_{\text {fuel }}^{-1}\right)$ & 0 & -32 & 25 \\
Cost $\left(\mathrm{US} \$^{\text {a }} \mathrm{GJ}\right.$ fuel & 7.5 & 8.9 & 10.8 \\
\hline
\end{tabular}

a 2002 value. 
The results for yield are reproduced in the Table 4 below, where biomass $\eta$ is the ratio of the energy in the product fuel to the energy in the feed biomass, and the $\mathrm{CO}_{2}$ release is the mass of $\mathrm{CO}_{2}$ emitted per mass of fuel produced.

It is not clear why the volumes given for Route 4 are less than the theoretical calculated above, although it is partly accounted for in the difference between the empirical formulas assumed for biomass.

In comparing the two estimates, they agree in estimating that the solar heat/solar hydrogen combination will reduce the required land area to one third of that required for standard gasification. Because of the different specific energies of the liquid products from the two analyses (methanol $=19.7 \mathrm{MJ} \mathrm{kg}{ }^{-1}$ and isooctane $=48 \mathrm{MJ} \mathrm{kg}^{-1}$ ), any comparison between the two should be made on the basis of the land required to produce a given amount of energy. For the standard gasification of switchgrass, the figures arrived at are nearly the same, namely $51 \mathrm{~m}^{2}$ per GJ per year for methanol and $47 \mathrm{~m}^{2} \mathrm{GJ}^{-1} \mathrm{yr}^{-1}$ for isooctane. With the application of solar heating and hydrogen, the figures fall to 17 and $16 \mathrm{~m}^{2} \mathrm{GJ}^{-1} \mathrm{yr}^{-1}$ respectively. This represents a reduction of almost $2 / 3$ of the land area required.

The energy efficiency of the current gasification process by Dietenberger [3] is given as $50 \%$, which is higher than that given by Hertwich (42\%) [18]. The former believe that this figure can be raised to $80 \%$ by process improvements, which would also curtail $\mathrm{CO}_{2}$ emissions from 4.63 to $1.54 \mathrm{~kg} \mathrm{~kg}^{-1}$. With external heat addition, such as from solar, the energy efficiency rises to 100 and the carbon dioxide emission falls to $1.14 \mathrm{~kg} \mathrm{~kg}^{-1}$. The energy efficiency with external heating and external hydrogen addition rises to $150 \%$ for petrol (147\% for diesel). This should be compared with $137 \%$ calculated above from thermochemical considerations. In this case hydrogen may be produced by solar thermochemical splitting of water [69].

Any analysis of biomass use must consider the availability of water, which is heavily involved in the process chemistry, and is an essential service. With biomass there is always inherent water which should be used as a reactant if the process is configured to accommodate it. There is an indication in the references that switchgrass requires only moderate soil quality and fertiliser application to give a yield of $20 \mathrm{t} \mathrm{ha}^{-1} \mathrm{yr}^{-1}$. All continents are experiencing fresh water stress [70], so that this aspect of such a program requires careful management.

A practical application can be made for the population of a town of 15,000 , who in the Australian context currently use an average of $2200 \mathrm{~L}$ per year per person [71]. This gives a total of 60 tonnes per day of hydrocarbon fuels (petrol plus diesel). In order to process 100 tpd of dry biomass $\left(\mathrm{CH}_{1.4} \mathrm{O}_{0.6}\right)$, which theoretically gives $61 \mathrm{tpd}$ of hydrocarbon fuel $\left(\mathrm{CH}_{2.1}\right)$, the collection areas for biomass and solar energy can be calculated. The processes considered will be the conventional gasification process, gasification with solar energy and gasification with a combined solar heat/hydrogen system. The agricultural areas required to produce 100 tonnes of dry weight per day to supply the gasification plants continuously with three different types of biomass are given in Table 5. Cane is assumed to give a yield of $44 \mathrm{t} \mathrm{ha}^{-1} \mathrm{yr}^{-1}$, switchgrass 18 and eucalypts $4 \mathrm{t}$ $\mathrm{ha}^{-1} \mathrm{yr}^{-1}$ of dry matter.

Table 4

Evaluation of hydrocarbon production from biomass [3].

\begin{tabular}{lclll}
\hline Technology & Biomass $\eta(\%)$ & $\mathrm{CO}_{2}$ release & Petrol $(\mathrm{l} / \mathrm{t})$ & Diesel $(\mathrm{l} / \mathrm{t})$ \\
\hline 1. Current CFB & 50 & 4.63 & 253 & 231 \\
2. Self-sufficient heat CFB & 80 & 1.54 & 406 & 370 \\
3. External heat only & 100 & 1.14 & 507 & 463 \\
4. External heat and $\mathrm{H}_{2}$ & $150(147)$ & 0 & 760 & 681 \\
\hline
\end{tabular}

Table 5

Estimated land requirements to service a town of 15,000 , or a city of 4 million people with hydrocarbon fuels at current Australian consumption rates.

\begin{tabular}{|c|c|c|c|c|c|c|}
\hline & \multicolumn{2}{|l|}{ Cane } & \multicolumn{2}{|c|}{ Switchgrass } & \multicolumn{2}{|c|}{ Eucalypt } \\
\hline & $15 \mathrm{k}$ town & $\begin{array}{l}4 \mathrm{M} \\
\text { city }\end{array}$ & $\begin{array}{l}15 \mathrm{k} \\
\text { town }\end{array}$ & $\begin{array}{l}4 \mathrm{M} \\
\text { city }\end{array}$ & $\begin{array}{l}15 \mathrm{k} \\
\text { town }\end{array}$ & $\begin{array}{l}4 \mathrm{M} \\
\text { city }\end{array}$ \\
\hline $\begin{array}{l}\text { Yield } \\
\quad\left(\mathrm{t}_{\mathrm{dry}} \mathrm{ha}^{-1} \mathrm{yr}^{-1}\right)\end{array}$ & 44 & & 18 & & 4 & \\
\hline Cycle (yr) & 1 & & 1 & & 3 & \\
\hline Rainfall (mm pa) & Irrigation & & $380-75$ & & 365 & \\
\hline $\begin{array}{l}\text { Fertilizer use } \\
\text { Crop Area }\left(\mathrm{km}^{2}\right)\end{array}$ & Heavy & & Light & & Nil & \\
\hline Std. gasification & 21 & 5600 & 51 & 13,500 & 230 & 61,000 \\
\hline Gasif/solar & 10.4 & 2800 & 15 & 6700 & 114 & 30,000 \\
\hline $\begin{array}{l}\text { Gasif/solar/sol H} \mathrm{H}_{2} \\
\text { Solar area }\left(\mathrm{km}^{2}\right)\end{array}$ & 6.9 & 1840 & 17 & 4500 & 75 & 20,000 \\
\hline Gasif/solar & 0.5 & 133 & 0.5 & 133 & 0.5 & 133 \\
\hline Gasif/solar/sol $\mathrm{H}_{2}$ & 2.7 & 700 & 2.7 & 700 & 2.7 & 700 \\
\hline
\end{tabular}

The area under crop for conventional gasification must be $21 \mathrm{~km}^{2}$ for cane (assumed to contain $45 \%$ moisture), around $51 \mathrm{~km}^{2}$ for switchgrass and $230 \mathrm{~km}^{2}$ for the eucalypts. The areas required for cropping with solar heating are also given, based on the data of Hertwich [18] i.e. half that of standard gasification. The area for collecting this solar energy is the same for all three crops.

An important consideration in the application of this technology will be the heat transfer load from the intermediate fluid. If $4.5 \mathrm{MJ} \mathrm{kg}^{-1}$ are required for the gasification step (see above), the energy demand for the reactor is $5.2 \mathrm{MW}$ continuously. The wallto-bed heat transfer coefficient will be around $500 \mathrm{~W} \mathrm{~m}{ }^{-2} \mathrm{~K}^{-1}$ [72]. If a mean temperature difference of $100 \mathrm{~K}$ is achievable, the reactor surface area needed to serve 15,000 people is $\sim 100 \mathrm{~m}^{2}$. In comparison the estimated area needed for this service using cyclone reactors based on the results of Lédé [37-40] is $140 \mathrm{~m}^{2}$.

The land area required for collecting solar energy for reaction and hydrogen generation according to Hertwich is approximately one sixth of that required for cropping i.e. $1.2 \mathrm{~km}^{2}$ for switchgrass. Extra collection area is required for overnight energy storage in order to run the plant in a quasi-continuous manner. Consequently, we have made the following estimates.

In the case of biomass processing using solar heat alone, if the estimate of $40 \%$ solar-to-chemical energy plant efficiency [16] is considered in combination with a 15 h heat storage capacity, the solar field size is $40 \mathrm{MW}_{\text {th }}$, which represents a collection area of about $0.5 \mathrm{~km}^{2}$.

If concentrated solar energy provide heat for biomass processing and hydrogen production one must add to the previous area the collection area for hydrogen production. Charvin at al [73] have estimated the productivity of solar plant based on the $\mathrm{ZnO} / \mathrm{Zn}$ thermochemical cycle. A $50 \mathrm{MW}_{\mathrm{th}}\left(0.6 \mathrm{~km}^{2}\right)$ can produce 1.1 ton $\mathrm{H}_{2}$ / day in region with medium solar resources (DNI - direct normal irradiation $-1800 \mathrm{kWh} / \mathrm{m}^{2}$ ) such as in the south of France, and 1.5 ton $\mathrm{H}_{2}$ /day in a more favourable region (DNI $2500 \mathrm{kWh} / \mathrm{m}^{2}$ ). Consequently at the mean productivity of 1.31 ton day ${ }^{-1}$, the collection area associated with the hydrogen plant in our example $\left(15,000\right.$ people) is $2.2 \mathrm{~km}^{2}$. The total area required for thermal and chemical generation is therefore $2.7 \mathrm{~km}^{2}$.

Thus the land area covered by the energy system is always much smaller than the area of the crop it replaces, as thermal/chemical capture is far more efficient than photosynthetic capture. For the solar heating configuration, the total required land area is almost halved.

When the production cost of methanol fuel as estimated by Hertwich is converted to the hydrocarbon equivalent, the price is 31 US cents per litre (2002 money) for the conventional gasification 
route, or $26 \mathbb{\uparrow} / \mathbf{l}$ for the solar option. This would be competitive with current pump prices.

On a larger scale, the estimated minimum areas required to serve a city of 4 million people at current consumption rates (106 TJ pa) are also given in Table 5 . The requisition of land for this size of operation will involve considerable social upheaval. The areas required for solar operation are small in comparison, and within the calculation tolerance for the cropping land. Probable values are $133 \mathrm{~km}^{2}$ for process energy alone, and $700 \mathrm{~km}^{2}$ for process and hydrogen supply. This places the solar option in a strong position, as it leads to a considerable diminution in the land requirement.

\section{Conclusion}

The production of synthetic fuels from biomass via gasification has been addressed, with emphasis on the application of supplementary high temperature solar energy. The background of high temperature solar (solar concentrating) is discussed, including the proposed methods of contact between solar radiation and biomass/ steam reactants. The gasification of biomass for liquid fuel production is addressed in regards to biomass carbon content and hydrogen/oxygen ratio. Simple mass and energy balances describing the technological approach are developed, and compared with other studies with respect to efficiency and yield. Various types of biomass resource suitable for different agricultural conditions are compared. The review shows that significant benefits could be gained with external (solar) heating of the standard gasification process.

\section{References}

[1] Nashawi IS, Malallah A, Al-Bisharah M. Forecasting world crude oil production using multicyclic Hubbert model. Energ Fuel 2010;24:1788-800.

[2] Graves C, Ebbesen SD, Mogensen M, Lackner K. Sustainable hydrocarbon fuels by recycling $\mathrm{CO}_{2}$ and $\mathrm{H}_{2} \mathrm{O}$ with renewable or nuclear energy. Renew Sust Energ Rev 2011;15:1-23.

[3] Dietenberger MA, Anderson M. Vision of the U.S. biofuel future: a case for hydrogen-enriched biomass gasification. Ind Eng Chem Res 2007;46: 8863-74.

[4] Shapouri H, Duffield TA, Wang M. accessed at, The energy balance of corn ethanol: an update. USDA, www.transportation.anl.gov/pdfs/AF/265.pdf; 2002.

[5] Baumlin S, Broust F, Bazer-Bachi F, Bourdeaux T, Herbinet O, Ndiaye FT, et al. Production of hydrogen by lignins fast pyrolysis. Int J Hydrogen Energy 2006; 31:2179-92.

[6] Shuangning X, Zhihe L, Baoming L, Weiming Y, Xueyuan B. Devolatilisation characteristics of biomass at flash heating rates. Fuel 2006;85:664-70.

[7] Mauviel G, Fairouz K, Mar SR, Ferrer M, Lédé J. Attrition-free pyrolysis to produce bio-oil and char. Bioresour Technol 2009;100:6069-75.

[8] Inguanzo M, Dominguez A, Menéndez JA, Blanco CG, Pis JJ. On the pyrolysis of sewage sludge: the influence of pyrolysis conditions on solid, liquid and gas fractions. J Anal Appl Pyrolysis 2002;63:209-22.

[9] Tzanetakis T, Ashgriz N, James DF, Thomson MJ. Liquid fuel properties of a hardwood-derived bio-oil fraction. Energy \& Fuels 2008;22:2725-33.

[10] Guo LJ, Zhao L, Jing DW, Lu YJ, Yang HH, Bai BF, et al. Solar hydrogen production and its development in China. Energy 2009;34:1073-90.

[11] Bridgewater AV. The technical and economic feasibility of biomass gasification for power generation. Fuel 1995;34:631-53.

[12] Nzihou A. Toward the valorisation of waste and biomass. Waste Biomass Valor 2010;1(1):3-7.

[13] Kodama T. High temperature solar chemistry for converting solar heat to chemical fuels. Prog Energ Combust Sci 2003;29:567-97.

[14] Z'Graggen A, Steinfeld A. Heat and mass transfer analysis of a suspension of reacting particles subjected to concentrated solar radiation - Application to the steam-gasification of carbonaceous materials. Int J Heat Mass Transfe 2009;52:385-95.

[15] Fletcher EA. Solarthermal processing: a review. J solar energy Eng, Trans ASME 2001; 123:63-74.

[16] Pitz-Paal R, Bolero NB, Steinfeld A. Heliostat field layout optimisation for high temperature solar thermochemical processing. Solar Energy 2011;85:334-43.

[17] Segal A, Epstein M. Comparative performances of 'tower top' and 'tower reflector' central receiver. Solar Energy 1999;65:207-26.

[18] Hertwich EG, Zhang X. Concentrating-solar biomass gasification process for a 3rd generation biofuel. Env Sci Tech 2009;43:4207-12.
[19] Flamant G. Thermochimie solaire à hautes temperatures, résultats, expérimentaux. Quelques perspectives d'application. Revue de physique appliquée 1980;15:503-11

[20] Buck R, Bräuning T, Denk T, Pfänder M, Schwarzbözl P, Tellez F. Solar-hybrid gas turbine-based power tower systems (REFOS). J Solar Energy Eng 2002; 124:2-9.

[21] Jenkins BM, Baxter LL, Miles Jr TR, Miles TR. Combustion properties of biomass. Fuel Proc Tech 1998;54:17-46.

[22] Zhang W. Automotive fuels from biomass via gasification. Fuel Proc Tech 2010;91:866-76.

[23] Devi KL, Ptasinski KJ, Janssen FJJG. A review of the primary measures for tar elimination in biomass gasification processes. Biomass \& Bioenergy 2003;24: 125-40.

[24] Koskata: www.koskata.com

[25] Melchior T, Perkins C, Lichty P, Weimer AW, Steinfeld A. Solar-driven biochar gasification in a particle-flow reactor. Chem Eng Proc Process Intensification 2009;48:1279-87.

[26] Melchior T, Perkins C, Weimer AW, Steinfeld A. A cavity-receiver containing a tubular absorber for high temperature thermochemical processing using concentrated solar energy. Int J Therm Sci 2008;47:1496-503.

[27] Matsuoka K, Kuramoto K, Murakami T, Suzuki Y. Steam gasification of woody biomass in a circulating dual bubbling bed system. Energ Fuel 2008;22:1980-5.

[28] Ju F, Chen H, Yang H, Wang X, Zhang S, Liu D. Experimental study of a commercial circulated fluidised bed coal gasifier. Fuel Proc Tech 2010;91: $818-22$.

[29] Murakami T, Xu G, Suda T, Matsuzawa Y, Tani H, Jujimori T. Some process fundamentals of biomass gasification in a dual fluidized bed. Fuel 2007;86: 244-55.

[30] Kramreiter R, Url M, Kotik J, Hofbauer H. Experimental investigation of a $125 \mathrm{~kW}$ twin-fire fixed bed gasification pilot plant and comparison to the results of a 2 MW combined heat and power plant. Fuel Proc Tech 2008; 89:90-102.

[31] Han LJ, Kim $\mathrm{H}$. The reduction and control technology of tar during biomass gasification/pyrolysis: an overview. Renew Sust Energ Rev 2008;12:397-416.

[32] Rabou LPLM, Zwart RWR, Vreugdenhil BJ, Bos L. Tar in biomass producer gas, the energy research centre of the Netherlands (ECN) experience: an enduring challenge. Energ Fuel 2009;23:6189-98.

[33] Yung MM, Jablonski WS, Magrini-Bair KA. Review of catalytic conditioning of biomass-derived syngas. Energ Fuel 2009;23:1874-87.

[34] Boutin OF, Ferrer M, Lédé J. Flash pyrolysis of cellulose pellets submitted to a concentrated radiation: experiments and modelling. Chem Eng Sci 2002;57: $15-25$.

[35] Boutin OF, Ferrer M, Lédé J. Radiant flash pyrolysis of cellulose - evidence for the formation of short lifetime intermediate liquid species. J Anal Appl Pyrolysis 1998:47:13-31.

[36] Lédé J, Blanchard F, Boutin O. Radiant flash pyrolysis of cellulose pellets: products and mechanisms involved in transient and steady state conditions. Fuel 2002;81:1269-79.

[37] Lédé J. The cyclone: a multifunctional reactor for the fast pyrolysis of biomass. Ind Eng Chem Res 2000;39:893-903.

[38] Lédé J, Verzaro F, Antoine B, Villermaux J. Flash pyrolysis of wood in a cyclone reactor.

[39] Lédé J, Broust F, Ndiaye FT, Ferrer M. Proroperties of bio-oils produced by biomass fast pyrolysis in a cyclone reactor. Fuel 2007;86:1800-10.

[40] Lédé J. Comparison of contact and radiant ablative pyrolysis of biomass. J Anal Appl Pyrolysis 2003;70:601-18.

[41] Lédé J, Mercadier J. Simulation of the thermal cracking of biomass derived vapours, by the model reaction of decomposition of isocyuranic acid. J Anal Appl Pyrol 2003;67:295-305.

[42] Baumlin S, Broust F, Ferrer M, Meunier N, Marty E, Lédé J. The continuous self stirred tank reactor: measurement of the cracking kinetics of biomass pyrolysis vapours. Chem Eng Sci 2005;60:41-55.

[43] Gordillo ED, Belghit A. A bubbling fluidised bed solar reactor model of biomass char high temperature steam-only gasification. Fuel Proc Tech 2011;92: 314-21.

[44] Gordillo ED, Belghit A. A downdraft high temperature steam-only solar gasifier of biomass char: a modelling study. Biomass Bioenerg 2011;35: 2034-43.

[45] Steinfeld A. Solar thermochemical production of hydrogen - a review. Solar Energ 2005;78:603-15.

[46] Di Blasi CD, Hernandez EG, Santoro A. Radiative pyrolysis of single moist wood particles. Ind Eng Chem Res 2000;39:873-82.

[47] Piatkowski N, Wieckert C, Steinfeld A. Experimental investigation of a packedbed solar reactor for the steam-gasification of carbonaceous feedstocks. Fuel Proc Tech 2009;90:360-6.

[48] Piatkowski N, Wieckert C, Weimer AW, Steinfeld A. Solar-driven gasification of carbonaceous feedstock - a review. Energ Environ Sci 2011;4:73-82.

[49] Spritzer MH, Hong GT. Supercritical water partial oxidation. FY2003 Prog Rep Nat Renewable energy Lab, http://www1.eere.energy.gov/hydrogenandfuelcells/ pdfs/iib3_spritzer.pdf; 2003.

[50] Matsumura Y, Minowa T. Fundamental design of a continuous biomass gasification process using supercritical water fluidized bed. Int J Hydrogen Energ 2004;29(7):701-7.

[51] Demirbas A. Hydrogen-rich gas from fruit shells via supercritical water extraction. Int J Hydrogen Energ 2004;29(12):1237-43. 
[52] Rapagnà S, Jand N, Kiennemann A, Foscolo PU. Steam-gasification of biomass in a fluidised bed of olivine particles. Biomass Bioenerg 2000;19: 187-97.

[53] Juniper, www.enonac.org/documents/issues/sun.energy/juniper.pdf; 2008.

[54] Baidoo RR, Ferguson FF, Yeboah F.E. Exergy and energy analysis of plasma waste-to-power generation model. Distrib Gener Alt Energ J 24, 51-73

[55] Engelhaupt E. Do biofuels slow down global warming - or speed it up? Environ Sci Technol Jan 2008;15.

[56] Barker A, Pellow G, Pereira MDA. The sustainability of Brazilian sugarcane bioethanol: a literature review. EECA. Accessed from: www.eeca.govt.nz/all/ files/sustainability-brazilian-sugarcane-report-08.pdf; 2008.

[57] Mohan D, Pittman Jr CU, Steele PH. Pyrolysis of wood/biomass for bio-oil. Energ Fuel 2006;20:848-89.

[58] Harker JH, Backhurst JR. Fuel and energy. London: Academic Press; 1981

[59] Deicke R, Muller RL, Bieske GC. Growing sugar cane for ethanol production. Alcohol Fuels Conference. Sydney: IChemE; August 1978. p 7:10-15.

[60] Rinehart L. Accessed from: attra.ncat.org/attar-pub/switchgrass.html; 2006.

[61] Biello D. Grass makes better ethanol than corn does. Scientific Am Jan $2008 ; 8$.

[62] Vamvuka D, Topouzi V, Sfakiotakis S. Evaluation of production yield and thermal processing of switchgrass as a bio-energy crop for the Mediterranean region. Fuel Proc Tech 2010;91:988-96.

[63] McLaughlin SB, Kszos LA. Development of switchgrass (Panicum virgatum L.) bioenergy feedstock in the United States. Biomass Bioenerg 2005;28:515-35.
[64] West DR, Kincer DR. Yield of switchgrass as affected by seeding rates and dates. Biomass Bioenerg 2011;35:4057-9.

[65] Hartman JC, Nippert JB, Orozco RA, Springer CJ. Potential biological impacts of switchgrass (Panicum virgatum $L$.) biofuel cultivation in the central Great Plains USA. Biomass Bioenerg 2011;35:3415-21.

[66] Sochacki SJ, Harper RJ, Smetten KRJ. Estimation of woody biomass production from a short-rotation bio-energy system in semi-arid Australia. Biomass Bioenerg 2007;31:608-16.

[67] Wu H, Fu Q Giles R, Bartle J. Production of mallee biomass in Western Australia: energy balance analysis. Fuel Energ 2008;22:190-8.

[68] Bamford GR. Fuel alcohols seen through an oil company's eyes. Alcohol Fuels Conference pp 1:3-8, IChemE, Sydney, August 1978.

[69] Abanades S, Charvin P, Flamant G, Neveu P. Screening of water-splitting thermochemical cycles potentially attractive for hydrogen production by concentrated sloar energy. Energy 2006;31:2469-86.

[70] Pearce F. When the rivers run dry. London: Eden Project; 2006.

[71] AIP Australian Institute of Petroleum data. Accessed from: www.aip.com.au/ industry/facts.htm; 2009.

[72] Flamant G, Menigault T. Combined wall to fluidised bed heat transfer. Bubbles and emulsion contributions at high temperature. Int J Heat Mass Transfer 1987;30(9):1803-12.

[73] Charvin P, Abanades S, Neveu P, Lemort F, Flamant G. Dynamic Modeling of a Volumetric Solar Reactor for Volatile Metal Oxide Reduction » IchemE. Chem Eng Res Des 2008;86(11):1216-22. 